\title{
Translanguaging challenges in multilingual classrooms: scholar, teacher and student perspectives
}

\section{Anouk Ticheloven, Elma Blom, Paul Leseman \& Sarah McMonagle}

To cite this article: Anouk Ticheloven, Elma Blom, Paul Leseman \& Sarah McMonagle (2021) Translanguaging challenges in multilingual classrooms: scholar, teacher and student perspectives, International Journal of Multilingualism, 18:3, 491-514, DOI: 10.1080/14790718.2019.1686002

To link to this article: https://doi.org/10.1080/14790718.2019.1686002

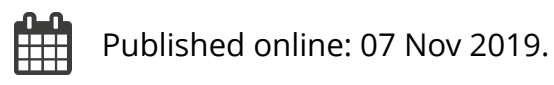

Submit your article to this journal ๘

Џ Article views: 1837

Q View related articles ๘

View Crossmark data ¿

Citing articles: 12 View citing articles $\sqsubset$ 


\title{
Translanguaging challenges in multilingual classrooms: scholar, teacher and student perspectives
}

\author{
Anouk Ticheloven (D) ${ }^{\mathrm{a}, \mathrm{b}}$, Elma Blom (D) ${ }^{\mathrm{a}}$, Paul Leseman (D) ${ }^{\mathrm{a}}$ and Sarah McMonagle (D) \\ ${ }^{\mathrm{a}}$ Faculty of Social Sciences, Utrecht University, Utrecht, Netherlands; ${ }^{\mathrm{b}}$ Institute for Intercultural and \\ International Comparative Education, Hamburg University, Hamburg, Germany
}

\begin{abstract}
The challenging task of establishing meaningful translanguaging in multilingual classrooms necessitates negotiation between different stakeholders. Such negotiation requires investigation of the contexts and ways in which translanguaging may be implemented as a suitable teaching strategy. The aim of the current study was to elicit practical and pedagogical issues of translanguaging in the classroom via interviews with three different groups of stakeholders: language education researchers, teachers, and multilingual learners. We visited four differently composed multilingual high schools from which concrete examples were recalled in semi-structured interviews on the topic of translanguaging with the selected stakeholders. Adopting an iterative study design, interviewees were presented with daily life examples from the school visits as well as statements from other stakeholder interviews. Their statements and reactions to the statements of others were recorded, qualitatively analysed and categorised. Overall, seven distinct pedagogical challenges concerning a translanguaging pedagogy emerged from the interview analysis: (1) Side effects; (2) Goal formulation; (3) Learning the language of schooling; (4) English and other semiotic resources; (5) Affective functions; (6) Effort; and (7) Confusion. These palpable pedagogic issues may be helpful in understanding how translanguaging in multilingual contexts can be implemented, thus bridging the gap between theory and practice.
\end{abstract}

\section{ARTICLE HISTORY}

Received 12 October 2018

Accepted 23 October 2019

\section{KEYWORDS}

Translanguaging; pedagogy; multilingualism; students; teachers; scholars

\section{Introduction}

Teachers are often confronted with different challenges in linguistically diverse classrooms. In particular, situations in which students speak languages of which teachers have no knowledge raise questions and can create dilemmas around language policy in the classroom. For instance, do students need their so-called 'home' languages ${ }^{1}$ to feel happy and safe? When do they need these languages? When and how can other languages be used as a resource for learning? (Dooly, 2005; García \& Wei, 2014). One pedagogy that addresses these questions and dilemmas is translanguaging.

Translanguaging has been described as both the ability of multilinguals to shuttle very easily between languages, without regard for socially and politically defined boundaries, and as a pedagogy through which teachers, by using scaffolding methods, enable 
children to see and use all of their languages for learning (García \& Kleyn, 2016; García \& Wei, 2014; Lewis, Jones, \& Baker, 2012a; but see: MacSwan, 2017). According to Cenoz and Gorter (2017, p. 910), 'Translanguaging is a recent and extremely successful concept in the area of bilingual and multilingual education that has gained wide acceptance in the literature in a short period of time.' Yet achieving meaningful translanguaging practices in the classroom is challenging (García \& Kleyn, 2016; Hornberger \& Link, 2012) and risks being romanticised or labelled as simplistic (Canagarajah, 2011a; García \& Kleyn, 2016). Canagarajah explains this stance as follows:

\footnotetext{
However, what they overlook is that translanguaging is a social accomplishment. Translanguaging not only involves a person drawing from all the languages in his/her repertoire to communicate, it also involves shuttling between the languages brought by the other to co-construct meaning. (...) It is a creative improvisation according to the needs of the context and local situation. (...) (Canagarajah, 2011a, pp. 4-5)
}

As Canagarajah (2011b, p. 8) moreover states: 'the pedagogical side is underdeveloped in general'. Indeed, Lewis, Jones, and Baker (2012b) confirm that a wealth of research is needed to establish when, where, and how translanguaging may be implemented as a suitable teaching approach in a multilingual context, in a systematic and purposeful manner (Probyn, 2015). The present study responds to such questions and criticisms by directly investigating some of the practical and pedagogical challenges that emerge among stakeholders (teachers, students, scholars) with regard to translanguaging in the multilingual classroom where teachers do not speak all of the students' languages.

\section{Why a translanguaging pedagogy?}

Translanguaging is a ground-up approach to teaching where learners become co-creators of knowledge. This idea is illustrated in Figure 1 which shows how student practices feed into teaching strategies. The role of the teacher is to activate and steer learners' individual input (e.g. Beres, 2015; Canagarajah, 2011a; 2011b; Lotherington, 2012).

The reason that the idea of translanguaging in education developed so quickly has to do, firstly, with the observation that translanguaging occurs among multilinguals anyway, whether teachers teach it or not (Canagarajah, 2011a; García \& Kleyn, 2016; García \& Wei, 2014). Secondly, it responds to concerns about the academic performance and well-being of students with immigrant backgrounds. Large-scale, international studies such as the OECD Programme for International Student Assessment (PISA) (OECD, 2015) have found that students with a migration background show lower educational attainment when compared with their non-immigrant peers (also described in Duarte \& Gogolin, 2013; Gogolin, 2002, 2011;). From a translanguaging perspective, these students are constrained in using their full linguistic repertoires and thus constrained in learning and expression (e.g. García \& Wei, 2014). Historically speaking, the lack of attention to students' home languages has been repeatedly presented as possibly having far-reaching negative effects (Cummins, 2001, 2007; Hornberger, 2003; Sierens \& Van Avermaet, 2014). While several initiatives have been developed for bi- or trilingual education and home language support $^{2}$ (Björklund et al., 2011; Gajo, 2014), translanguaging pedagogy is presented as a unique approach through which all students may use all of their language(s) in formal education, despite teachers not knowing those languages (García \& Wei, 2014). ${ }^{3}$ This is 


\section{Teaching practices} transfer, empowerment, collaboration in home language

Student practices

\section{Educational principle}

E.g. teaching for cross-linguistic

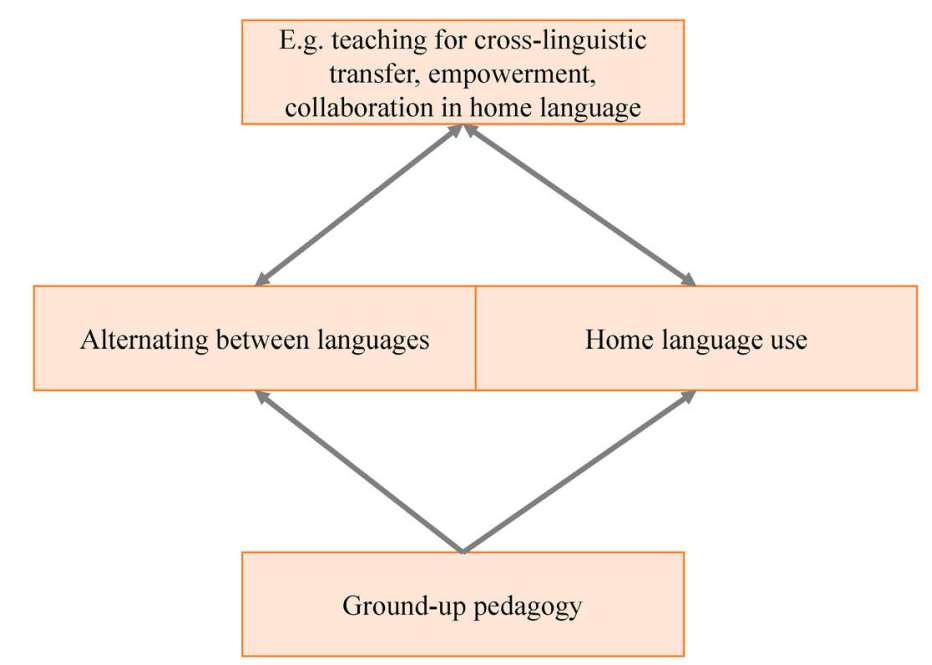

Figure 1. Some building blocks of translanguaging as pedagogy.

very different from, say, transitional education programmes that typically target specific languages (Reljić, Ferring, \& Martin, 2015).

Thirdly, translanguaging attempts to close the gap between students' different lifeworlds. Rather than present translanguaging as a 'service' to language minorities, researchers argue that translanguaging can produce benefits for all, including socalled 'majority' students. Encouraging students to recognise and use linguistic diversity, generally, as a resource for learning can help all students prepare for globally connected societies and changing working styles (García \& Wei, 2014; New London Group, 1996). These reasons to implement translanguaging in education have found great resonance. However, the critique emerges that the processes of implementing translanguaging have to be addressed more concretely (Canagarajah, 2011a; Lewis et al., 2012b).

In sum, research on translanguaging in education has been both praised as a unique answer to developments in changing societies as well as criticised for being too romanticised and pedagogically underdeveloped (García \& Kleyn, 2016). The present study responds by unpacking some of the pedagogical issues that emerge, or may be anticipated, during processes of negotiation over the use of a translanguaging pedagogy in multilingual schools.

\section{Parallel lines of research}

The versatility and details of a translanguaging pedagogy are based on psycholinguistic, educational linguistic and sociolinguistic research into language mixing. Both within and between these different disciplines, parallel lines of research exist. Below, we discuss a number of relevant findings from these three fields. Firstly, psycholinguistic research has shown that children are, from a very young age, capable of adapting their language and degree of language mixing to the interlocutor and context (cf. Petitto et al., 2001). This means that children become aware of the social boundaries surrounding 
their language use and are capable of distinguishing languages, even when they frequently mix them in practice (Genesee, 1989). Moreover, from a psycholinguistic perspective, mixing languages may be considered natural, especially for fluent bilinguals, as associative links exist within but also between languages (Lam \& Dijkstra, 2010). Consequently, having to avoid mixing in single-language contexts may be cognitively taxing (Green \& Abutalebi, 2013). If unintentional or 'erroneous' mixing happens (Canagarajah, 2011a, 2013), it is indeed the effect of less cognitive control (Festman \& Münte, 2012).

Secondly, with regard to formal education with older children and students, educational linguistic research indicates that language mixing in school is not detrimental to learning (Antón, Thierry, \& Duñabeitia, 2015; Antón, Thierry, Goborov, Anasagasti, \& Duñabeitia, 2016). Some studies have even shown an advantage for bilingual students - when compared with their monolingual peers - in learning semantic content, but only when learning occurs in mixed-language contexts (Thierry et al., as described in Lewis et al., 2012a). Positive effects of alternating languages in educational settings have also been found among students who were encouraged to express themselves in whichever language(s) they chose. This approach appeared to enable them to better demonstrate their understanding of subject content (e.g. Makalela, 2015; Vaish \& Subhan, 2015) and to better acquire and negotiate new knowledge (Duarte, 2016). Further arguments for the inclusion of home languages in education are that they may become lost when not formally supported, especially in the early years of school (Cenoz \& Gorter, 2017; Isurin, 2000; Janssen, Bosman, \& Leseman, 2013; Pallier et al., 2003), and that home languages can be beneficial to the development of academic skills, such as numeracy or cognitive ordering tasks (e.g. Van Tuijl, Leseman, \& Rispens, 2001) or foreign language learning (Maluch, Kempert, Neumann, \& Stanat, 2015). Despite the positive findings reported above, research into actual learning in specific domains and school subjects while alternating between languages is still scarce (Antón et al., 2015). Thirdly, from a sociolinguistic and affective perspective, rejection of home languages may lead to feelings of alienation and self-identity crises, especially with regard to immigrant languages of low status (e.g. Creese \& Blackledge, 2015; Cummins, 2001; Pulinx, Van Avermaet, \& Agirdag, 2017). While language status and hierarchies provide critical contexts for students' linguistic practices, both inside and outside school (e.g. Creese \& Blackledge, 2010b; 2015), translanguaging pedagogies may contribute to the development of a stronger multilingual identity (García-Mateus \& Palmer, 2017). Regarding analyses of the role of status and power in natural and spontaneous language use, a plethora of slightly different concepts have emerged in the sociolinguistic tradition: inter alia codemeshing (e.g. Young, Barrett, \& Lovejoy, 2014), translingual practices (e.g. Canagarajah, 2013), metrolingualism (Otsuji \& Pennycook, 2010). While we acknowledge the relevance of the debates between these sociolinguistic lines of research, discussing them in detail goes beyond the scope of this study.

\section{Steering translanguaging}

Translanguaging practices can be established in various ways, and often they occur naturally, but researchers also argue that they have to be taught explicitly, as elaborated here:

What current classroom studies show is that translanguaging is a naturally occurring phenomenon for multilingual students. (...) However, such studies might give the impression that 
translanguaging does not have to be taught. (...) This line of thinking leads to the tendency of multilingual scholars and researchers to romanticise the translanguaging practices of students. Most such studies do not identify any limitations or errors in the multilingual practices of the students. (Canagarajah, 2011a, p. 402)

Ways of teaching translanguaging explicitly are presented in the CUNY-NYSIEB-guide (City University of New York-New York State's Initiative for Emergent Bilinguals; Celic \& Seltzer, 2011). It begins by empowering students to use their languages via small actions and adaptations, such as making those languages visible in the classroom or by learning to say 'hello' in different languages (García \& Wei, 2014). To make these practices more meaningful, students can complete writing assignments in which they use all of their linguistic resources (Kiramba, 2017). Students can then collaborate in 'language pairs' using the language(s) of their choosing. This would preferably occur between students who have different levels of the language of schooling, as based on the principles of scaffolding (García \& Wei, 2014; Rosiers, Willaert, Van Avermaet, \& Slembrouck, 2016). Where such a strategy is impossible in terms of logistics, i.e. where languages are not equally represented in the classroom, students can be encouraged to compare languages, such as by searching for cognates in different languages for vocabulary development and morphological awareness (e.g. Lyster, Quiroga, \& Ballinger, 2013; Ticheloven, SchwenkeLam, \& Fürstenau, forthcoming, 2020). They can translate particular discourses or specific vocabulary, and then paraphrase in other languages (García \& Wei, 2014; Rosiers et al., 2016). Actively contrasting languages is considered beneficial for vocabulary expansion and reading comprehension (Kieffer \& Lesaux, 2007; Laufer \& Girsai, 2008; Nagy, Berninger, \& Abbott, 2006), and for metalinguistic awareness, which is associated with enhanced foreign language learning (Rauch, Naumann, \& Jude, 2012).

\section{The present study}

Individual differences between schools, students, teachers and districts will influence the negotiation process of when and how to implement translanguaging (Blommaert \& Van Avermaet, 2008; García \& Kleyn, 2016; Lundberg, 2019). Consequently, implementing translanguaging strategies and tailoring them to context is a task imbued with negotiation (Berliner, 2002; Dooly, 2007; Van der Wildt, Van Avermaet, \& Van Houtte, 2015). It is this point of negotiation that the present study seeks to explore. Research claims that, in such processes of negotiation, teachers and scholars should be viewed as equal, thus implying that teachers are not merely subjects within the process (Denton, Vaughn, \& Fletcher, 2003). In addition, Fullan (2007) describes how building a shared vision is necessary for the successful development of educational concepts and change. In this perspective, Barron (2006) stresses the importance of focusing on the initiatives and experiences of learners themselves when conducting educational research, especially when relying on learner-initiated practices.

In short, the need for building a bridge between the worlds of the different agents involved is critical (Berliner, 2002; Van Tartwijk, 2011). Qualitative studies that provide in-depth understanding of pedagogical issues and concerns from different viewpoints during the implementation of new educational concepts are thus highly relevant (Berliner, 2002; as cited in Van Tartwijk, 2011). To our knowledge, such studies do not yet exist with regard to translanguaging. The current study therefore aims to identify concrete challenges regarding 
translanguaging, based on interviews with scholars working in education and linguistics, teachers in multilingual schools, and multilingual students themselves. The research question that guides our study is: What kind of pedagogical challenges do scholars, teachers and students foresee or encounter when implementing translanguaging in multilingual classrooms?

\section{Method}

\section{Design}

We adopt the qualitative framework of phenomenology - with translanguaging in education as phenomenon - as we examine an existing theory from various viewpoints, rather than aiming to develop a new model or theory ourselves (Creswell, Hanson, Clark Plano, \& Morales, 2007; Groenewald, 2004; Starks \& Brown Trinidad, 2007). Phenomenology facilitates understanding the essence of translanguaging challenges in education. By following Moustakas's empirical and transcendental phenomenology, we attempted to set aside our own interpretations and understandings of this phenomenon. The goal was to take a fresh perspective by collecting data from several persons who may have experienced translanguaging in education in different ways (as described and cited in Creswell, 2007). Moreover, because the research question is explorative, the method is inductive, which allows for an open analysis - without need for deductive frameworks and rubrics.

We conducted interviews that did not seek general patterns or a theory, but a composite description of how different stakeholders may experience or anticipate translanguaging as pedagogy (Creswell et al., 2007). We included scholars from the disciplines of education sciences and linguistics $(N=16)$. We aimed to gain a multidisciplinary view on the practicability of translanguaging in concrete situations - a view which cannot yet be found in scholarship. In order to have concrete situations upon which to reflect in the course of the interviews, we attended lessons in five multilingual schools and conducted interviews with teachers $(N=7)$ and students $(N=31)$.

The study was iterative in nature, meaning that all interviews were tailored to the specific stage of the research. As interviews were ongoing, findings from previous interviews and classroom observations were continually included. These iterations were made explicit to the participants (Akkerman, Admiraal, Brekelmans, \& Oost, 2008). One example of such an interview impulse is outlined in the following:

Interviewer: In the classroom I visited last week, a student told me that he was happy that he did not have Arabic-speaking peers in his classroom anymore, so that he was now finally forced to speak Dutch. How do you see this?

This example denotes the interviewer-as-guide approach that we chose, meaning that we specified main topics in advance while keeping the exact sequence of questions flexible. By posing open questions, we expected interviewees to broach themes with which they themselves may be directly concerned or occupied (Cohen, Manion, \& Morrison, 2013). Scholars, teachers and students are therefore not equally represented in our findings as detailed below.

\section{Quality}

We minimised confirmation and researcher bias by pursuing variation both between and within given perspectives, by referring to both pro- and contra examples in interview 
discussions (Kaplan \& Maxwell, 2005; Pratt, 2009), by using different methods to gather information (interviews, observations), and by the consistent verification of findings (Onwuegbuzie \& Leech, 2007). The threat of social desirability was reduced by informing students that their interviews would be anonymised and by the interviewer expressing neutrality. Moreover, scholars and teachers were given the opportunity to evaluate the final result section, serving as a form of member checking $(\mathrm{MC})$, ensuring face validity, visibility and transparency of the research process (e.g. Cohen et al., 2013; Kaplan \& Maxwell, 2005). They did not suggest any changes.

\section{Lesson observations}

We observed lessons in four schools in the Netherlands in the cities of Gorinchem, Utrecht, and Rotterdam, in order to have palpable situations to discuss in the interviews. The classroom observations therefore served as a preparatory stage in the study, rather than to generate data for analysis. Two of these schools provided education for recently arrived immigrants, while the two others are international schools with lingua franca English. It was an explicit choice to choose this mix of school types - to collect a large range of possible pedagogical concerns, fitting the phenomenological nature of the study. Drawing on Yin's (2009) typology of case studies, we observed lessons that were typical in nature in order to capture the circumstances and conditions of commonplace classroom situations. English, Dutch, mathematics, and history lessons were observed.

\section{Interviews}

We used purposive sampling techniques by contacting participants from within our own network who also directed us to other potential participants via the snowball approach. We further consulted active and prominent researchers within the field (e.g. authors of relevant publications) and approached schools that explicitly promote themselves as multilingual. Respondents were selected based on their expertise and willingness to participate. As the sample sizes show, it was easiest to find students and hardest to find teachers who were willing to take part in the study. In accordance with the phenomenological framework, we aimed at a sample size of between $n=5$ and $n=25$ for all groups (Creswell et al., 2007; Polkinghorne, 2005). Over a four-month period in 2015 and 2016, we conducted 37 interviews with 55 participants (Table 1). We conducted the interviews individually or in small groups of between two and five people. Interviews were conducted in English, Dutch, or German; most were face-to-face, three were over Skype and two in written form. Different interview formats were implemented due to time and/or geographical constraints as well as participants' own preferences. The main themes in the interviews with the students entailed language background, daily language use, and

Table 1. Sample and interview details.

\begin{tabular}{lcccc}
\hline $\mathrm{N}$ & Scholars & Teachers & Students & Total \\
\hline$N$ Participants & 16 & 8 & 31 & 55 \\
$N$ Interviews & 16 & 7 & 14 & 37 \\
$N$ Fragments & $762(M=50.8)$ & $221(M=31.6)$ & $254(M=18.1)$ & $1237(M=33.4)$ \\
$N$ Duration & $415 \mathrm{~min}$ & $218 \mathrm{~min}$ & $169 \mathrm{~min}$ & $802 \mathrm{~min}$ \\
\hline
\end{tabular}


attitudes towards languages used in education (as based on existing questionnaires: Li, Sepanski, \& Zhao, 2006; Luk \& Bialystok, 2013; Marian, Blumenfeld, \& Kaushanskaya, 2007). In the interviews with teachers and scholars, the concept of translanguaging was addressed more explicitly than in the interviews with the students.

\section{Sample data}

The scholars that we interviewed were all researchers in linguistic and/or education sciences. Among those willing to participate, most of them $(n=13)$ were trained at the doctoral level or higher and came from the Netherlands $(n=10)$, Germany $(n=3)$, USA $(n=2)$. Students ranged in age from 11 to 25 years, and all had a migration background. ${ }^{4}$ Overall they varied in age $(M=13.83, S D=4.26)$, languages spoken and proficiency in each, as well as migration histories. Most student participants attended the schools in which observations took place $(n=21)$; others $(n=10)$ were approached via the authors' personal networks and the snowball approach. For all participants there was a procedure of active consent. For students younger than 12 years $(n=3)$, parents were informed of the aims and running of the study. Parents as well as participating students were given the opportunity to decline the use of interview data for publication. All teachers but one worked at the schools where lessons were observed.

\section{Data analysis}

We coded all interview fragments using an open coding strategy. A new fragment began when a different aspect, situation or context was introduced in each interview, resulting in 1,237 fragments (see Table 1). The length of each fragment varied from a couple of words to a few sentences. Coding began after the first interview, in line with the guidelines of abductive (i.e. categories emerge iteratively) constant comparison (e.g. Boeije, Van Wesel, \& Alisic, 2011; Onwuegbuzie \& Leech, 2007). Concepts and topics of debate were gathered inductively from the data. In short, the data analysis can be summarised as moving from code to category to concept - the latter is referred to in our study as 'pedagogical challenge' - while simultaneously collecting new data (Lichtman, 2012). For the purposes of the present article, we have solely selected those pedagogical challenges in which all stakeholder perspectives are represented, and in which we can distinguish more than one distinct viewpoint. Seven main pedagogical challenges emerged from the interview analyses, namely:

(1) Side effects,

(2) Goal formulation,

(3) Learning the language of schooling,

(4) English and other semiotic resources,

(5) Affective functions,

(6) Effort,

(7) Confusion.

In light of the phenomenological nature of this study, we do not give indications of the frequency of occurring views. Moreover, the three participant groups are not equally 
represented in each issue as we intended to highlight a variety of viewpoints. For instance, where students expressed relatively different viewpoints on a particular matter but scholars mostly agreed on the same matter, more student citations appear accordingly in that section of the results.

\section{Results}

To answer the research question about the kinds of pedagogical issues that scholars, teachers and students anticipate or encounter when implementing translanguaging in multilingual classrooms, we had initially intended to present their views as distinct groups. Interestingly, however, more differences emerged within the respective groups, rather than between them. Due to overlaps, the views of scholars, teachers and students are therefore incorporated under each of the seven challenges identified, and not group by group. We conclude each challenge with links to theory and literature and with suggestions for future research.

\section{Challenge 1: side effects}

This first pedagogical issue highlights the concern that using other languages in the classroom may have undesired side effects. Isolating students was a fear expressed in all three experts groups, partly based on parental concerns: 'A parent complained (...) because the teacher allowed other languages during break time. Her kid was the only Bulgarian in the group and did not understand a word of what other kids were saying.' (scholar and teacher). Students expressed linguistic isolation also in terms of awkwardness: 'I think translanguaging can help, but sometimes it doesn't because then the other person doesn't understand and then it is, like, awkward' (11 year old, International School). However, generally speaking, as long as students did not feel excluded, they were positive about other languages in the classroom. Moreover, they described adjusting their behaviour to the interlocutors they are with. Although the following example reveals that students may be aware of the need to adjust behaviours to interlocutor and context, they do not always do this:

Boy 2 Yeah, there are two guys in grade 7 who are also Spanish and we (...) always speak Spanish and then when there are people who don't speak Spanish ...

Girl 2 You still speak Spanish.

Girl 1 Yeah, sometimes when we are with them in a conversation we kind of try to also speak Spanish with them.

Girl 2 Hola.

Boy 2 No, we speak English when we are in a conversation with them! Of course we do .... Well, we mix... We mix.

- 12 and 11 year old (International School)

This fragment touches upon deeper issues, such as language status, identity construction, and the high degree to which language choice is social. Yet, generally speaking, this obvious awareness of interlocutor and context is, from a scholarly perspective, a confirmation of research (e.g. Petitto, 2009; Petitto et al., 2001), supporting the idea that children are capable of adapting their language and degree of language mixing to the interlocutor and context. 
Not only students, but also teachers may feel isolated when confronted with other languages. A teacher (Newcomer Education), for example, described an incident in which another teacher in the school was referred to as a whore in Polish by a student. He explained that such incidents raise teachers' suspicion regarding multilingualism. Another teacher reacted to this incident by arguing that these issues do not have to do with translanguaging and languages, but with politeness because: 'at the end of the day, it is all about being caring and respectful and that's it and as long as you drum that in there is no need for specific rules about languages' (teacher, International School).

Another teacher argued that other languages in the classroom prevent teachers from keeping track of what students are doing. This fear was frequently discussed in the interviews, and most often raised by teachers. Some teachers described feelings of discomfort when they do not know what students are discussing in class time. In reaction to this sentiment, some scholars argued that teachers simply cannot always know what students are discussing anyway, even when they just use the language of schooling, because 'hey, they are teenagers' (Scholar of Language and Education). Moreover, it was suggested that teachers can conclude from students' non-verbal language whether or not they are working seriously (Scholar of Bilingual Education). One teacher (Newcomer Education) attempted to solve this dilemma by separating students who spoke the same languages. When they required a 'language timeout' they were allowed to raise their hands and to ask another student a question in their common language. Another teacher argued that they are unable to intervene if students teach incorrect assumptions or content in another language (Newcomer Education). One scholar reacted that, although these fears are highly understandable, they might also be ungrounded as 'there is always a need for a lingua franca. Always. So, when there are 11 languages and the teacher says in Dutch "now listen to me", the 11 other languages will stop and the students will listen' (Scholar of Linguistics).

Despite scholarly nuances and solutions, teacher struggles remain, as revealed by a teacher who is very open to the ideas of translanguaging and encourages all languages in her classroom, being bilingual Italian-English herself.

And now what happens in my classroom is that the Italian speaking ones break up in the middle of a sentence and be like 'how do I say that in Italian?' And those are very difficult moments for me. Because everything that happens in the classroom should be a learning experience for everyone. (...) So absolutely, there is this flipside that you have to be careful that speakers don't use their languages to isolate others. (teacher, International School)

Some teachers in the newcomer classrooms therefore felt inclined to separate students who speak the same language and to not allow other languages during lessons, although they intrinsically encouraged the idea of using other languages. They view the organisational stress and risk of losing control as more significant than the principle of linguistic inclusion. Scholars strongly disagreed with this, while the student group was split.

This pedagogical issue of undesired effects has been addressed in research into attitudes and beliefs (e.g. Pulinx et al., 2017) and in practical guidelines for translanguaging (e.g. Celic \& Seltzer, 2011), but less so in empirical classroom studies (e.g. García \& Kleyn, 2016). Rather than any sort of intrinsic stand against translanguaging per se, it has more to do with teacher concerns regarding exclusion and control in the classroom. 
A recommendation for future research would be to tackle such purely pedagogical challenges by taking a holistic approach to multilingualism in the classroom. This implies a simultaneous consideration of both teachers' and pupils' cognitive, linguistic and symbolic challenges when implementing translanguaging-like strategies (Duarte \& Günther-van der Meij, 2018). Moreover, the general quality of teacher-student interaction ought to be investigated (see Berliner, 2002; Van Tartwijk, 2011).

\section{Challenge 2: goal formulation}

A second pedagogical challenge that emerged from the coding analysis was the desirability of ground-up teaching, the importance of having general learning goals, and how this teaching can contribute to achieving those goals. In short, one scholar of educational linguistics summarised the tension between constraining students by having strict procedures versus not guiding them in their formal learning:

If you want to build a house, you can't build it on the holes, you have to build a fundament. And the fundament is what students or pupils can already practice. In that sense, I think this [ground-up teaching] is right. (...) BUT teaching is also normative. You have certain aims. (...) And the next steps of what has to be learned, don't develop from what students already can, but they develop from an external perspective. (...). Learners don't know this next step.

In line with the latter part of the fragment, a scholar of educational psychology stressed that the learning goal must always be in the forefront: 'The goal is always the primary issue. Always. I can't do anything with "if". My starting point needs to be: "what do I want to achieve?"'. Only after establishing the goal, they continued, can the next step be taken, such as the decision to include other languages. Translanguaging goals were primarily discussed by the interviewed scholars: 'Is it all about an attitude issue or is it something more, is it language as a resource? (...) Is it about "acknowledging multilingualism", "being impressed by multilingualism", and "showing multilingualism", or is it "using multilingualism"?" (Scholar of Linguistics). Connected to this, another scholar stated that without clear goals a pro-multilingual stance may be prone to tokenism (Scholar of Linguistics). A teacher interviewee (International School), who was raised bilingually himself and therefore pro-multilingualism, did not completely share this concern. According to him, tokenism is already a step in the right direction, because 'schools are still proud to disseminate the message "at our school we only speak Dutch"'.

With regard to student opinion and practices, although many reported translanguaging in informal situations, they had highly different opinions as to whether or not it could be helpful in their learning, when steered by the teacher:

'I think it [mixing languages] is pretty much fun to do and I think we can learn more. First, I say it like in English and then in my other language and then it just sticks in my head, because I thought of it in two languages' (12 year old International School); 'I really love it, because normally if you don't know something you are just like whatever let it go, but now you can really, really discuss it' (12 year old International School). ${ }^{5}$

Those who felt less positively about translanguaging encouraged by their teacher expressed fears of becoming confused or not fully acquiring the language of schooling. Others simply did not recognise the need for translanguaging in formal learning. These matters will be discussed further under later issues. 
A teacher (International School) also doubted whether translanguaging can help in learning: 'And then they switch and they hear all the languages, which is great, but that doesn't fold to subject learning. So, be careful how much time you dedicate to that in the classroom.' A scholar of language education added to this by mentioning another risk, namely that translanguaging and the actual needs of students might be misinterpreted:

(...) And you run the risk of top-down imposing, and, again, the risk of completely misunderstanding ... (...). So, there is a discussion concerning what do we do with this. ${ }^{6}$ And there is the fear that when it gets into the hands of the wrong people ... that it is misinterpreted.

And then the conservative models will just continue to be perpetuated.

As a result, the scholar stated, even ground-up teaching can become normative, which stands in contrast to the intended effect. Students also recognised this risk: 'Then I maybe do want to use my other languages, but when I have the feeling that I have to use them, I get tired.' (11-year-old International School). Other scholars also recognised this: 'Sometimes what happens is that teachers plan for it and then (...) students do not react so much (...), maybe some students don't want to speak their home languages' (Scholar of Bilingual Education). According to the group of scholars, student reluctance is ascribed to many causes, such as individual student differences and preferences, the classroom climate, social and monolingual forces, feelings of shame, but also the suitability of the chosen translanguaging strategy. At the same time, as shown by the enthusiastic student reactions above, others feel positive about translanguaging in the classroom. Therefore, on the issue of 'goals formulation', we see that reactions are mixed.

The cautious discussion around normative translanguaging teaching and its goals that implies top-down implementation falls in line with scholarship. The 'risk of tokenism' referred to by one of the scholars, recalls so-called 'sugar-coating' in educational attempts to establish continuity between students' in-school and out-of-school practices that become superficial and non-sensical, and do not contribute to actual learning, especially when teachers feel little affinity with those ideas (Bronkhorst \& Akkerman, 2016; García \& Sylvan, 2011). The difference between sugar-coating and meaningful translanguaging could be examined via different research methods, separately, that focus on distinct translanguaging goals in the affective, cognitive as well as social domains. This would build on the literature outlined in the introduction to the present article, which states that translanguaging as pedagogy is still underdeveloped (e.g. Canagarajah, 2011a).

\section{Challenge 3: learning the language of schooling}

Translanguaging inevitably occurs in lessons where students are not yet fluent in the language of schooling, despite teachers not always supporting the practice:

(...) Sometimes teachers do it because they feel like there is no other option, because the speakers do it anyway and because they need it to be understood. (...) Although it is a good sign that they are motivated, it is not in line with their intrinsic beliefs about multilingualism. (Scholar of Language and Education)

This aligns with the view of a teacher interviewee who prefers to avoid the use of other languages: 'To be completely honest now, I fear that it is counterproductive for the learning process of the Arabic speaking students that you speak their language.' (Teacher 
Newcomer Education). Another teacher (International School) argued for immersion over translanguaging when it comes to learning, but that translanguaging-like strategies are simply unavoidable:

We all believe in full immersion, don't we? Those ideas are doubted as well. Yeah.. Well, that is not me, I think it works. But (...) we are not robots. In terms of language learning ... It is emotional. And you don't want students who feel trapped in an environment in which they feel they cannot express themselves.

The challenge thus appears to revolve around balancing between two perceived evils: student mutism and scaffolding as crutch. On the one hand, silencing languages can lead to unengaged students, as recognised in all three expert groups. On the other hand, what is perceived to be 'too much' translanguaging or use of other languages might impede acquisition of the language of schooling, which is necessary for educational achievement. When students are not forced, at some points, to use the language of schooling, the fear was expressed in all participant groups that they may become complacent and less motivated to learn in the language of schooling. A student, for example, stated that he was very happy that he no longer had Arabic-speaking peers in his classroom, as he was now forced to speak Dutch.

On the one hand, scholars all supported the first viewpoint that a lack of translanguaging can lead to silent and unengaged students and they unanimously disagreed with the idea of full immersion. On the other hand, they varied in the extent to which other languages can, could and should be integrated in education and which translanguaging strategies are best suited to which contexts. Yet, from a teacher perspective, external forces and stress are given as reasons for preferring immersion, especially in newcomer education: 'It is hard to grapple with it [the integration of students with different home languages]. Somehow overwhelming. (...) And it may all turn out right, but it may also completely go in the wrong direction. And what if we don't manage to work it around?' (Teacher Newcomer Education). Clearly, teachers had doubts concerning the best approach, as expressed by a teacher (Newcomer Education) who declared herself to be pro-immersion, but who simultaneously noticed that language knowledge is not always needed to succeed in school:

Somehow two Greek girls are not in the extra programme with more Dutch-language support, but just in the regular programme. I have no idea why. And then I realised at some point 'wow, how bad your Dutch actually still is ...... But they are really getting away with it. Yeah, in Dutch assessments I see, their Dutch is really, really bad, but they can somehow deal with it in the regular programme.

This example was enthusiastically received by scholars and will be elaborated in the next section.

This third pedagogical challenge is closely related to the learning context. Generally, in educational sciences, it is a truism that context matters (Berliner, 2002). Context includes factors such as the school curriculum, national standards and budgets (Datnow, 2005) which often strongly emphasise the learning of the school language in order to prepare students for a successful future. However, although translanguaging also considers the language of schooling to be essential, when focusing on this alone, the complexities of language and language status become visible (Sembiante, 2016). Recognition of existing monolingual norms is therefore essential to understand that language use is negotiated, contextualised and interwoven with ideological factors, and that translanguaging is not a 
synonym for not learning the language of schooling or for not learning at all (Creese \& Blackledge, 2010a, 2011; Gogolin, 2002, 2011; Hornberger, 2003).

\section{Challenge 4: English and other semiotic resources}

The fourth pedagogical issue concerns semiotic resources that can be used to make meaning aside from the students' own linguistic repertoires. These might include gestures, a smart board with pictures, picture dictionaries, or English as global lingua franca. Sometimes, English as second lingua franca was chosen over the use of both the home language and the language of schooling:

It feels like English defines me. It feels like home. I really love to express myself in English, I don't know why.. (...) I mean, English is the most important language of the planet, how can you not want to learn that language? - Romanian student, 15 years old.

A student ( 23 years old) expressed a similar attitude and ascribed his preference for English to the fact that he has always listened to English music. On account of feelings that may be expressed through music, for him, the English language lends itself best to describing feelings, even more so than his home language (Turkish) or the language of schooling (Dutch) which he learned to speak fluently. The student interviewees in particular agreed that other resources, including English, can serve the same goal as involving the mother tongue, and that it might indeed be easier than mother tongue inclusion, because then at least everybody has a chance of understanding.

When it comes to English, however, some teachers were reluctant. Firstly, not all students speak English due to their different backgrounds, leading to the same dilemmas as translanguaging with home languages (e.g. 'Chinese students normally don't speak English') (Teacher, Newcomer Education). Secondly, another teacher (International School) explains that English is sometimes 'seen as the enemy', because the risk of students no longer trying to learn the societal language is considered even higher when using English, a language that is considered to be socially ubiquitous. Thirdly, another teacher (Newcomer Education) points out that some students may like English, that their English is, however, not better than their Dutch, but they 'just think it is cool to speak English'. At the same time, another teacher (Newcomer Education) did state that the use of English is sometimes the smoothest way to keep the lesson going.

The use of other semiotic resources, like gestures and pictures, led to different ideas among the scholars. Partly, one sees a generally low theoretical interest in those resources:

I associate all of this with structuralist views about isolating languages. They left out all the other semiotic resources, like colours, sounds, space, everything. Partly it was to make meaning controllable, (...) but the problem is that some of the resources were isolated, and others got left out. (Scholar of Applied Linguistics and English)

A scholar who agreed with the view that the use of gestures is used too infrequently (Scholar of Multilingualism) suggested combining the Accelerative Integrated Method (AIM) for teaching a foreign language (which uses gestures while learning a foreign language) with translanguaging, to move beyond a focus on home languages and towards full linguistic repertoires. Yet, another scholar (Applied Linguistics) then argued that this would extend the theory too much and that it would digress from the main message. 
Research has long philosophised the benefits of other semiotic resources and multiple modalities of communication in schools (Canagarajah, 2013; García, Bartlett, \& Kleifgen, 2007; New London Group, 1996), also as part of translanguaging (García \& Wei, 2014). However, to the best of our knowledge, it has not been sufficiently researched how this could work in practice in multilingual schools as part of translanguaging strategies. We see this, including the potential of new technologies, as another recommendation for future research.

\section{Challenge 5: affective functions}

In contrast to the inconclusive views between and within expert groups in the previous sections, the encouragement of other languages was unanimously recognised as serving direct affective functions. Even the teachers who expressed doubts vis-à-vis translanguaging in the classroom changed attitude when it came to direct emotional issues:

Of course we see that students cannot do without their own languages. When they are sad. When they are having a fight. This involves emotion. (...) And then we find a solution, (...) And then it is really no problem when they use their own language. (teacher, Newcomer Education)

While this teacher focuses on negative emotions, a student pointed out that language also serves other affective functions and that, in her opinion, teachers tend to forget that:

When we first moved, the school principal kind of forbade us to talk to each other in our mother tongue, which was so freaking unfair (...). We had just moved there, none of us had friends and none of us could talk or express ourselves. (...) Frankly speaking, I don't think the teachers gave a damn. - Romanian student, 15 years old.

In addition to this fragment, a student (14 year old, Newcomer Education) described missing his language, particularly when he wants to make a joke, more than when expressing negative emotions. One scholar (Applied Linguistics) added to this by describing a case with Chinese students living in England - they were very successful in their study but unhappy because they were unable to act in informal English speech. Aside from the different ways in which people see the role of language in expressing different emotions, all participants agreed on the importance of one's own language to be used as a safe haven.

The need to examine the role of socioemotional factors, such as well-being, in multilingual teaching and learning has been acknowledged in other recent research. For example, research into social homophily has shown that students made more cross-linguistic friendships when schools promote multilingualism (Van der Wildt et al., 2015). Duarte and Günther-van der Meij (2018) claim 'positive motivational and attitudinal aspects' to be one of the three main dimensions in holistic multilingual teaching. ${ }^{7}$ Moreover, research has demonstrated how multilinguals experience emotions differently in different languages and how they use language differently in different emotional states (Dewaele, 2008; Williams, Srinivasan, Liu, Lee, \& Zhou, 2019). There is clearly space for such lines of research to incorporate the role of translanguaging strategies in multilingual communication. Conversely, we see research avenues for translanguaging research to connect with existing studies on socioemotional factors for language learning. 


\section{Challenge 6: effort}

The sixth pedagogical issue concerns the effort for both teachers and students to structurally use translanguaging. Firstly, from a teacher perspective, when students can already speak the language of schooling, translanguaging strategies may slow the lesson down. In contrast, one teacher (International School) explained how he halts his lessons to explain the background of words and how they may relate to other languages in the classroom: 'And yes, of course that takes time. But I think that is education. And not running through the curriculum. (...) And my students always pass their exams.' Standpoints varied on this matter, however, with some teachers doubting that the extra time and effort are worth it in terms of learning.

Translanguaging may also demand more effort of students who do not feel fluent in their home language(s): 'My mother sometimes texts me in Bosnian, but spelling is something completely different. I always reply in Dutch, which she perfectly understands as well' (19-yearold student). For this student, Dutch is the easiest language in which to work and in a translanguaging classroom he would probably not use Bosnian as it would be too much effort to do so, he reported. Yet, students who felt fluent in their home language, still sometimes reported feeling more comfortable with the language of schooling, because 'that is the language we have the homework and tests in' (12-year-old International School).

According to one teacher, this lack of confidence in home languages may lead students to feeling 'a bit lost between languages' (Teacher, International School) and may make translanguaging more difficult, particularly as teachers do not normally speak the other languages and cannot help with clarifications in those languages. Yet, some scholars perceive this very 'being lost between languages' as good reason to introduce a translanguaging pedagogy, as it can play a role in sustaining or further developing the home language, thus creating stronger multilingual development. This may indeed be demanding in terms of teaching effort, but looking at the supposed effects, it may also be desirable. Students also perceive translanguaging as a potential means to sustain the home language: 'I am really fine with speaking Dutch, but sometimes I feel like I am losing my Arabic. That scares me.' (14-year-old, Newcomer Education); 'If I can use my Danish for my homework, I still have a little bit from home' (11-year-old, International School).

Seeking a compromise between using translanguaging for long-term benefits and a lingua franca to keep the lesson going smoothly, one teacher (International School) considered allocating translanguaging practices to homework or to some very specific, selfcontained tasks: 'and then the rest is just in English.' An advantage of translanguaging in homework, according to her, is that parents can get involved. This was also recognised and affirmed by scholars. Another teacher (International School) suggested organising 'translanguaging days, 'translanguaging hours' or 'translanguaging blocks' (for example the last ten minutes of a lesson) to have the advantages of translanguaging without slowing down and disturbing regular lessons.

Differing perspectives on the 'right' amount of 'other' languages for learning correspond to García and Kleyn (2016), who also argue that translanguaging could, in some instances, be restricted:

While it is good for emergent bilinguals in schools to sometimes inhibit part of their linguistic repertoire, it is definitely and decidedly also good for them sometimes, perhaps most of the time, to deploy it fully and naturally and freely, that is, to translanguage. $(2016$, p. xi) 
In order to find the 'right' kind of translanguaging for learning, then, further research could clarify in which moments it can work best: certain subjects, types of assessment, working styles (collaborative learning, individual assignments, etc.), specific ages, and learner group composition could be given more in-depth consideration in future studies (see also e.g. Gorter, 2017).

\section{Challenge 7: confusion}

The final pedagogical challenge concerns confusion. Some students admit to becoming confused when alternating languages: 'I think my brain does not work like that. I can do, like, one thing at one time. Like, one language at one time' (12-year-old, International School). Other students reported becoming confused only on days when other languages are used a lot: 'When I am using all the languages at once, my brain just goes like WHIEHIEHIEHIE' (12-year-old, International School). Another student elucidated this point further:

Sometimes, all these languages in my head really slow down my reaction. (...) then sometimes (...) the word I want to say only pops up in another language. And then I really have to think hard before I remember it in the right language. It feels like a blockade. (23-year-old student)

Another student expressed the fear that she may not be able to separate her languages anymore in the future: 'I like it, but nowadays I know what I am speaking and if I continue translanguaging my speaking and writing will get mixed and then sometimes people may not understand me anymore...' (12-year-old, International School).

At the same time, not all students experience this confusion (or fear of confusion), and some even expressed joy in mixing languages: 'Mixing languages? Oh, that's me. I do it all the time'. (12-year-old student, International School). These mixed attitudes to mixing languages prompted the following reaction from a teacher interviewee:

As we saw this week, it does confuse some of the students and why is it always good to put them in that confusion? (...) Some students would thrive on confusion because that makes them work it out and learn more. And some students, and I would have been one of them, would just drown. And as a teacher you need to make sure that you cater to both of those different types of students. It is not fair that you put the drowning students always in the condition of confusion. (...). (Teacher, International School)

One scholar (Applied linguistics and English) contradicted this teacher by arguing that confusion is part of society and is thus inevitable: 'We cannot always guess what language the other person is going to speak. (...) The problem is that a lot of linguistics and language teaching want to teach predictability'. One teacher (International School) expressed the expectation that confusion could be reduced by introducing students earlier to translanguaging at school, because 'at 16 they are so... (...). They are used to, for 15 years they have been making sure that they keep their languages separate'. Yet, a perceived implication of introducing translanguaging at a young age is that students need to be explicitly trained in using the right repertoire in the right situation because it might 'not just happen' (Scholar of Educational Linguistics).

Specifically, with regard to this debate, a teacher expressed a wish for neuropsychological studies that could provide answers to such questions of confusion: 'Like you know, mechanically, what is happening in our brains when we do this? And can you prove it?' 
(Teacher, International School). We would welcome such research, as psycholinguistic empirical research suggests thus far that languages are connected in bilingual brains (e.g. Bosma, Blom, Hoekstra, \& Versloot, 2019; Lam \& Dijkstra, 2010). Yet, some students and teachers state that they actually do feel confused. Future research could investigate the role of age here, but also the role of children's own feelings and fears while mixing.

\section{Conclusion and discussion}

To address the question, What kind of pedagogical challenges do scholars, teachers and students anticipate or encounter when implementing translanguaging in multilingual classrooms?, we conducted interviews with relevant scholars in different subfields, teachers working in multilingual schools, and multilingual students. The strength of this study is its breadth; the chosen approach to consult a range of stakeholders managed to capture both a variety of pedagogical challenges (real or perceived) as well as different views on those challenges. This may help to substantiate translanguaging research in multilingual contexts, as well as to defend it against criticisms of being romanticised or too narrowly focused (e.g. only in bilingual contexts).

A limitation of this study is that the interviewee sample was selective and other perspectives may have been overlooked. This may especially hold true for the teacher group. Those interviewed for the present study had experience teaching in highly diverse classrooms. Since research suggests that teacher tolerance towards other languages increases with more diversity (Pohan, Ward, Kouzekanani, \& Boatright, 2009; Pulinx et al., 2017), the relatively open teacher attitude demonstrated in the present study, especially regarding the affective functions of translanguaging, may be directly related to experience of high diversity. Due to the explorative approach, which sought a breadth of perspectives on the topic of translanguaging, we did not collect additional background data on our subjects. The present analysis therefore rests solely on the interview data. As an avenue for further research, we would recommend collecting additional data to clarify the ways in which the standpoints of the various experts relate to their respective contexts and backgrounds. Still, acknowledging such limitations, and as a starting point, the findings presented here show that to implement translanguaging in the classroom, negotiation is required (attitudes and experiences aside).

From the interviews conducted, seven pedagogical challenges have been highlighted that point to the requirement of negotiation. Firstly, some palpable issues emerged on the classroom level, such as side effects (challenge 1) and on the individual level, such as affective functions (challenge 5), effort (challenge 6) and confusion (challenge 7). Yet, other issues were debated on a more abstract level, relatively independently from the specific educational contexts, such as goal formulation (challenge 2), learning the language of schooling (challenge 3) and English and other semiotic resources (challenge 4). On all issues, we found both consensus and inconclusiveness within and between the stakeholder groups. This study is therefore by no means conclusive on the matter of translanguaging as pedagogy, and makes suggestions for further research as highlighted by the key findings summarised here. Firstly, although there was relatively high consensus on the positive relationship between translanguaging and well-being, students stressed other types of well-being (making friends, making jokes) than did most teachers, who primarily stressed the importance of translanguaging for dealing with negative emotions, 
such as feeling mad or sad. We suggest that future research scrutinises the relationship between translanguaging and different aspects of socioemotional well-being.

Secondly, the magnitude of individual differences between students with regard to confusion was somewhat surprising as it does not fall in line with the scholarship that suggests language-mixing is a natural practice for any multilingual speaker. Yet, it could be that students mix languages more than they reported in the interviews, or that social desirability played a role. This would be another matter for further investigation. Different views on the negative effects of confusion were also notable: while scholars and some teachers saw confusion as something students could be trained to overcome, especially when translanguaging is introduced at a young age, other teachers and students considered it a hindrance to learning.

Thirdly, it is further remarkable that scholars appeared to disagree on the desirable amount and form of translanguaging in the classroom. For instance, although all teachers reported using other semiotic resources to make meaning in groups with emergent majority language learners, scholars disagreed on the use of other semiotic resources such as gestures and pictures. Future research should empirically investigate how such other semiotic resources may moderate teaching and learning with translanguaging for both students and teachers.

Last, our results indicate that newly arrived migrants have different needs with regard to their home languages in education than those students who are already more confident in the language of schooling. Verification of these needs and what they might mean for translanguaging strategies are required (see also dependent and independent translanguaging, García \& Wei, 2014).

In short, this study attempted to draw lines of parallel research from different subfields and we would strongly recommend this strategy in future studies on how systematic and purposeful translanguaging can become part of a multilingual school culture. Through fuller investigation, we can see how and whether translanguaging as a successful concept in the relevant literature can be negotiated as equally successful classroom practice. While the present study may have raised as many questions as it can answer, so long as gaps persist between theory and practice, direct consultation with stakeholders as equals can provide hints on how these gaps may be bridged. As linguistic diversification is a reality in classrooms across Europe, effective learning must be realised for all students. This necessitates careful negotiation between teacher experience and professionalism, the needs of multilingual students, and empirical enquiry that supports pedagogical processes. This study has provided such a starting point.

\section{Notes}

1. We adopt the term 'home languages' to refer to those languages, other than the language of schooling, which are transmitted to students in their families. We follow leading international translanguaging studies (e.g. as Celic \& Seltzer, 2011; García \& Kleyn, 2016) as well as European multilingual education studies (e.g. Duarte, 2016; Pulinx et al., 2017). The authors are well aware of debates concerning terminology in this field. Other terms include, for instance, mother tongue and heritage language.

2. Examples include CLIL (e.g. Coyle, 2007) and transitional bilingual education models (e.g. Slavin, Madden, Calderón, Chamberlain, \& Hennessy, 2011). 
3. It should be noted that parallel lines of research that use different definitions also exist (Gorter, 2017). For example, Functional Multilingual Learning is another name for a multilingual pedagogy (Sierens \& Van Avermaet, 2014).

4. By migration background we refer to students and/or their parents who were born outside of the Netherlands. Home languages in this study included Turkish, Bosnian, Arabic, Chinese, Danish, Spanish, Dutch, Romanian, Punjabi, Hindi, Portuguese, Bulgarian, and Polish.

5. These two students had to describe the atmosphere in a Disney video by avoiding frequently used words like 'nicé or 'biǵ. They were tasked with making mind maps by using all of their languages, and to seek appropriate words in those languages. They could talk among each other in the languages they wanted, as long as they excluded nobody. Afterwards, they searched together for the correct words in the language of schooling, so they could discuss the assignment in the language that everybody understood. They also did homework in their home languages.

6. This refers to translanguaging pedagogy.

7. They call it 'the symbolic' dimension.

\section{Disclosure statement}

No potential conflict of interest was reported by the authors.

\section{ORCID}

Anouk Ticheloven (1) http://orcid.org/0000-0002-7389-5197

Elma Blom (D) http://orcid.org/0000-0001-8984-3650

Paul Leseman (iD http://orcid.org/0000-0003-1286-0510

Sarah McMonagle (1) http://orcid.org/0000-0002-6226-6352

\section{References}

Akkerman, S., Admiraal, W., Brekelmans, M., \& Oost, H. (2008). Auditing quality of research in social sciences. Quality \& Quantity, 42, 257-274.

Antón, E., Thierry, G., \& Duñabeitia, J. A. (2015). Mixing languages during learning? Testing the one subject-one language rule. PloS one, 10, 1-20.

Antón, E., Thierry, G., Goborov, A., Anasagasti, J., \& Duñabeitia, J. A. (2016). Testing bilingual educational methods: A Plea to End the language-mixing Taboo. Language Learning, 66, 29-50.

Barron, B. (2006). Interest and self-sustained learning as catalysts of development: A learning ecology perspective. Human Development, 49, 193-224.

Beres, A. M. (2015). An overview of translanguaging: 20 years of 'giving voice to those who do not speak'. Translation and Translanguaging in Multilingual Contexts, 1, 103-118.

Berliner, D. C. (2002). Comment: Educational research:The hardest Science of All. Educational Researcher, 31, 18-20.

Björklund, S., Cabianca, A., Cenoz, J., Ehrhardt, S., Etxague, X., Garau, M. J., ... Bangma, I. (2011). Trilingual primary education in Europe: Some developments with regard to the provisions of trilingual primary education in minority language communities of the European Union. Leeuwarden: Mercator.

Blommaert, J., \& Van Avermaet, P. (2008). Taal, onderwijs en de samenleving: De kloof tussen beleid en realiteit. [language, education and society: The gap between policy and reality]. Berchem: Epo.

Boeije, H. R., Van Wesel, F., \& Alisic, E. (2011). Making a difference: Towards a method for weighing the evidence in a qualitative synthesis. Journal of Evaluation in Clinical Practice, 17, 657-663.

Bosma, E., Blom, E., Hoekstra, E., \& Versloot, A. (2019). A longitudinal study on the gradual cognate facilitation effect in bilingual children's Frisian receptive vocabulary. International Journal of Bilingual Education and Bilingualism, 22, 371-385. 
Bronkhorst, L. H., \& Akkerman, S. F. (2016). At the boundary of school: Continuity and discontinuity in learning across contexts. Educational Research Review, 19, 18-35.

Canagarajah, S. (2011a). Codemeshing in academic writing: Identifying teachable strategies of translanguaging. The Modern Language Journal, 95, 401-417.

Canagarajah, S. (2011b). Translanguaging in the classroom: Emerging issues for research and pedagogy. Applied Linguistics Review, 2, 1-28.

Canagarajah, S. (2013). Literacy as translingual practice: Between communities and classrooms. New York: Routledge.

Celic, C., \& Seltzer, K. (2011). Translanguaging: A CUNY-NYSIEB guide for educators. New York: CUNYNYSIEB.

Cenoz, J., \& Gorter, D. (2017). Minority languages and sustainable translanguaging: Threat or opportunity? Journal of Multilingual and Multicultural Development, 38, 901-912.

Cohen, L., Manion, L., \& Morrison, K. (2013). Interviews. In L. Cohen, L. Manion, \& K. Morrison (Eds.), Research methods in education (pp. 409-442). London: Routledge.

Coyle, D. (2007). Content and language integrated learning: Towards a connected research agenda for CLIL pedagogies. International Journal of Bilingual Education and Bilingualism, 10, 543-562.

Creese, A., \& Blackledge, A. (2010a). Translanguaging in the bilingual classroom: A pedagogy for learning and teaching? The Modern Language Journal, 94, 103-115.

Creese, A., \& Blackledge, A. (2010b). Towards a sociolinguistics of superdiversity. Zeitschrift für Erziehungswissenschaft, 13, 549-572.

Creese, A., \& Blackledge, A. (2011). Separate and flexible bilingualism in complementary schools: Multiple language practices in interrelationship. Journal of Pragmatics, 43, 1196-1208.

Creese, A., \& Blackledge, A. (2015). Translanguaging and identity in educational settings. Annual Review of Applied Linguistics, 35, 20-35.

Creswell, J. W. (2007). Qualitative inquiry and research design: Choosing among five approaches. Thousand Oaks: Sage publications.

Creswell, J. W., Hanson, W. E., Clark Plano, V. L., \& Morales, A. (2007). Qualitative research designs selection and implementation. The Counseling Psychologist, 35, 236-264.

Cummins, J. (2001). Bilingual children's mother tongue: Why is it important for education. Sprogforum, 19, 15-20.

Cummins, J. (2007). Rethinking monolingual instructional strategies in multilingual classrooms. Canadian Journal of Applied Linguistics/Revue Canadienne de Linguistique Appliquée, 10, 221-240.

Datnow, A. (2005). The sustainability of comprehensive school reform models in changing district and state contexts. Educational Administration Quarterly, 41, 121-153.

Denton, C. A., Vaughn, S., \& Fletcher, J. M. (2003). Bringing research-based practice in reading intervention to scale. Learning Disabilities Research and Practice, 18, 201-211.

Dewaele, J. M. (2008). The emotional weight of I love you in multilinguals' languages. Journal of Pragmatics, 40, 1753-1780.

Dooly, M. (2005). How aware are they? Research into teachers' attitudes about linguistic diversity. Language Awareness, 14, 97-111.

Dooly, M. (2007). Constructing differences: A qualitative analysis of teachers' perspectives on linguistic and cultural diversity. Linguistics and Education, 18, 142-166.

Duarte, J. (2016). Translanguaging in mainstream education: A sociocultural approach. International Journal of Bilingual Education and Bilingualism, 1, 1-15.

Duarte, J., \& Gogolin, I. (2013). Introduction: Linguistic superdiversity in educational institutions. In J. Duarte \& I. Gogolin (Eds.), Linguistic superdiversity in urban areas: Research approaches (pp. 1-26). Amsterdam: John Benjamins B.V.

Duarte, J., \& Günther-van der Meij, M. (2018). A holistic model for multilingualism in education. EuroAmerican Journal of Applied Linguistics and Languages, 5, 24-43.

Festman, J., \& Münte, T. F. (2012). Cognitive control in Russian-German bilinguals. Frontiers in Psychology, 3, 1-7.

Fullan, M. (2007). The new meaning of educational change. New York, London: Routledge.

Gajo, L. (2014). From normalization to didactization of multilingualism: European and Francophone research at the crossroads between linguistics and didactics. In J. Conteh, \& G. Meier (Eds.), The 
multilingual turn in languages education: Opportunities and challenges (pp. 113-131). Bristol: Multilingual matters.

García-Mateus, S., \& Palmer, D. (2017). Translanguaging pedagogies for positive identities in two-way dual language bilingual education. Journal of Language, Identity \& Education, 16, 245-255.

García, O., Bartlett, L., \& Kleifgen, J. (2007). From biliteracy to pluriliteracies. In P. Auer, \& L. Wei (Eds.), Handbook of applied linguistics (pp. 207-228). Berlin: Walter de Gruyyter.

García, O., \& Kleyn, T. (2016). Translanguaging with multilingual students: Learning from classroom moments. Abingdon: Routledge.

García, O., \& Sylvan, C. E. (2011). Pedagogies and practices in multilingual classrooms: Singularities in pluralities. The Modern Language Journal, 95, 385-400.

García, O., \& Wei, L. (2014). Translanguaging: Language, bilingualism and education. Hampshire and New York: Palgrave Macmillan.

Genesee, F. (1989). Early bilingual development: One language or two? Journal of Child Language, 16, $161-179$.

Gogolin, I. (2002). Linguistic and cultural diversity in Europe: A challenge for educational research and practice. European Educational Research Journal, 1, 123-138. doi:10.2304/eerj.2002.1.1.3.

Gogolin, I. (2011). The challenge of super diversity for education in Europe. Education Inquiry, 2, 239249.

Gorter, D. (2017). Bringing language education policy and multilingual assessment closer. Language and Education, 31, 191-196.

Green, D. W., \& Abutalebi, J. (2013). Language control in bilinguals: The adaptive control hypothesis. Journal of Cognitive Psychology, 25, 515-530.

Groenewald, T. (2004). A phenomenological research design illustrated. International Journal of Qualitative Methods, 3, 42-55.

Hornberger, N. H. (2003). Continua of biliteracy: An ecological framework for educational policy, research, and practice in multilingual settings. Clevedon: Multilingual Matters.

Hornberger, N. H., \& Link, H. (2012). Translanguaging and transnational literacies in multilingual classrooms: A biliteracy lens. International Journal of Bilingual Education and Bilingualism, 15, 261-278.

Isurin, L. (2000). Deserted island or a child's first language forgetting. Bilingualism: Language and Cognition, 3, 151-166.

Janssen, M., Bosman, A. M., \& Leseman, P. P. M. (2013). Phoneme awareness, vocabulary and word decoding in monolingual and bilingual Dutch children. Journal of Research in Reading, 36, 1-13.

Kaplan, B., \& Maxwell, J. A. (2005). Qualitative research methods for evaluating computer information systems. In J. G. Anderson \& C. E. Aydin (Eds.), Evaluating the organizational impact of healthcare information systems (pp. 30-55). New York: Springer.

Kieffer, M. J., \& Lesaux, N. K. (2007). Breaking down words to build meaning: Morphology, vocabulary, and reading comprehension in the urban classroom. The Reading Teacher, 61, 134-144.

Kiramba, L. K. (2017). Translanguaging in the writing of emergent multilinguals. International Multilingual Research Journal, 11, 115-130.

Lam, K. J., \& Dijkstra, T. (2010). Word repetition, masked orthographic priming, and language switching: Bilingual studies and BIA+ simulations. International Journal of Bilingual Education and Bilingualism, 13, 487-503.

Laufer, B., \& Girsai, N. (2008). Form-focused instruction in second language vocabulary learning: A case for contrastive analysis and translation. Applied Linguistics, 29, 694-716.

Lewis, G., Jones, B., \& Baker, C. (2012a). Translanguaging: Origins and development from school to street and beyond. Educational Research and Evaluation, 18, 641-654.

Lewis, G., Jones, B., \& Baker, C. (2012b). Translanguaging: Developing its conceptualisation and contextualisation. Educational Research and Evaluation, 18, 655-670.

Li, P., Sepanski, S., \& Zhao, X. (2006). Language history questionnaire: A web-based interface for bilingual research. Behavior Research Methods, 38, 202-210.

Lichtman, M. (2012). Qualitative research in education: A user's guide: A user's guide. London et al.: Sage.

Lotherington, H. (2012). Pedagogy of multiliteracies: Rewriting Goldilocks. New York: Routledge. 
Luk, G., \& Bialystok, E. (2013). Bilingualism is not a categorical variable: Interaction between language proficiency and usage. Journal of Cognitive Psychology, 25, 605-621.

Lundberg, A. (2019). Teachers' viewpoints about an educational reform concerning multilingualism in German-speaking Switzerland. Learning and Instruction, 64, 1-8.

Lyster, R., Quiroga, J., \& Ballinger, S. (2013). The effects of biliteracy instruction on morphological awareness. Journal of Immersion and Content-Based Language Education, 1, 169-197.

MacSwan, J. (2017). A multilingual perspective on translanguaging. American Educational Research Journal, 54, 167-201.

Makalela, L. (2015). Moving out of linguistic boxes: The effects of translanguaging strategies for multilingual classrooms. Language and Education, 29, 200-217.

Maluch, J. T., Kempert, S., Neumann, M., \& Stanat, P. (2015). The effect of speaking a minority language at home on foreign language learning. Learning and Instruction, 36, 76-85.

Marian, V., Blumenfeld, H. K., \& Kaushanskaya, M. (2007). The language experience and proficiency questionnaire (LEAP-Q): Assessing language profiles in bilinguals and multilinguals. Journal of Speech, Language, and Hearing Research, 50, 940-967.

Nagy, W., Berninger, V. W., \& Abbott, R. D. (2006). Contributions of morphology beyond phonology to literacy outcomes of upper elementary and middle-school students. Journal of Educational Psychology, 98, 134-147.

New London Group. (1996). A pedagogy of multiliteracies: Designing social futures. Harvard Educational Review, 66, 60-93.

OECD. (2015). Immigrant students at school: Easing the journey towards integration, OECD Reviews of Migrant education. Paris: OECD Publishing.

Onwuegbuzie, A. J., \& Leech, N. L. (2007). Validity and qualitative research: An oxymoron? Quality and Quantity, 41, 233-249.

Otsuji, E., \& Pennycook, A. (2010). Metrolingualism: Fixity, fluidity and language in flux. International Journal of Multilingualism, 7, 240-254.

Pallier, C., Dehaene, S., Poline, J. B., LeBihan, D., Argenti, A. M., Dupoux, E., \& Mehler, J. (2003). Brain imaging of language plasticity in adopted adults: Can a second language replace the first? Cerebral Cortex, 13, 155-161.

Petitto, L. A. (2009). New discoveries from the bilingual brain and mind across the life span: Implications for education. Mind, Brain, and Education, 3, 185-197.

Petitto, L. A., Katerelos, M., Levy, B. G., Gauna, K., Tétreault, K., \& Ferraro, V. (2001). Bilingual signed and spoken language acquisition from birth: Implications for the mechanisms underlying early bilingual language acquisition. Journal of Child Language, 28, 453-496.

Pohan, C. A., Ward, M., Kouzekanani, K., \& Boatright, C. (2009). The Impact of field Placement Sites on Preservice teachers' beliefs about teaching diverse students. School-University Partnerships, 3, 4353.

Polkinghorne, D. E. (2005). Language and meaning: Data collection in qualitative research. Journal of Counseling Psychology, 52, 137-145.

Pratt, M. G. (2009). From the editors: For the lack of a boilerplate: Tips on writing up (and reviewing) qualitative research. Academy of Management Journal, 52, 856-862.

Probyn, M. (2015). Pedagogical translanguaging: Bridging discourses in South African science classrooms. Language and Education, 29, 218-234.

Pulinx, R., Van Avermaet, P., \& Agirdag, O. (2017). Silencing linguistic diversity: The extent, the determinants and consequences of the monolingual beliefs of Flemish teachers. International Journal of Bilingual Education and Bilingualism, 20, 542-556.

Rauch, D. P., Naumann, J., \& Jude, N. (2012). Metalinguistic awareness mediates effects of full biliteracy on third-language reading proficiency in Turkish-German bilinguals. International Journal of Bilingualism, 16, 402-418.

Reljić, G., Ferring, D., \& Martin, R. (2015). A meta-analysis on the effectiveness of bilingual programs in Europe. Review of Educational Research, 85, 92-128.

Rosiers, K., Willaert, E., Van Avermaet, P., \& Slembrouck, S. (2016). Interaction for transfer: Flexible approaches to multilingualism and their pedagogical implications for classroom interaction in linguistically diverse mainstream classrooms. Language and Education, 30, 267-280. 
Sembiante, S. (2016). Translanguaging and the multilingual turn: Epistemological reconceptualization in the fields of language and implications for reframing language in curriculum studies. Curriculum Inquiry, 46, 45-61.

Sierens, S., \& Van Avermaet, P. (2014). Language diversity in education: Evolving from multilingual education to functional multilingual learning. In D. Little, C. Leung, \& P. van Avermaet (Eds.), Managing diversity in education: Languages, policies, pedagogies (pp. 204-221). Ontario: Multilingual matters.

Slavin, R. E., Madden, N., Calderón, M., Chamberlain, A., \& Hennessy, M. (2011). Reading and language outcomes of a multiyear randomized evaluation of transitional bilingual education. Educational Evaluation and Policy Analysis, 33, 47-58.

Starks, H., \& Brown Trinidad, S. (2007). Choose your method: A comparison of phenomenology, discourse analysis, and grounded theory. Qualitative Health Research, 17, 1372-1380.

Ticheloven, A., Schwenke-Lam, T., \& Fürstenau, S. (forthcoming, 2020). Multilingual pedagogies in German primary classrooms: Language comparisons. In J. Duarte, \& C. Kirsch (Eds.), Multilingual approaches for teaching and learning. From acknowledging to capitalizing on multilingualism in European mainstream education. Abingdon: Routledge.

Vaish, V., \& Subhan, A. (2015). Translanguaging in a reading class. International Journal of Multilingualism, 12, 338-357.

Van der Wildt, V. A.,Van Avermaet, P., \& Van Houtte, M. (2015). Do birds singing the same song flock together? A mixed-method study on language as a tool for changing social homophily in primary schools in Flanders (Belgium). International Journal of Intercultural Relations, 49, 168-182.

Van Tartwijk, J. W. F. (2011). Van onderzoek naar onderwijs, of de kunst van de toepassing. Utrecht: Lecture Utrecht University.

Van Tuijl, C., Leseman, P. P., \& Rispens, J. (2001). Efficacy of an intensive home-based educational intervention programme for 4- to 6-year-old ethnic minority children in the Netherlands. International Journal of Behavioral Development, 25, 148-159.

Williams, A., Srinivasan, M., Liu, C., Lee, P., \& Zhou, Q. (2019). Why do bilinguals code-switch when emotional? Insights from immigrant parent-child interactions. Emotion, Advance online publication.

Yin, R. K. (2009). Case Study Research, Design \& Methods 4th ed. In The Information Systems Research Challenge (Harvard Business School Research Colloquium). London: Sage.

Young, V. A., Barrett, R., \& Lovejoy, K. B. (2014). Other people's English: Code-meshing, code-switching, and African American literacy. New York: Teachers College Press. 